\title{
A Evaluation on the Working Capital Management
}

\author{
Pavithra, Kaliyamurthi, P.Thamilselvam.
}

\begin{abstract}
This assignment deal with the "A Study on the Evaluation of Working Capital Management with reference to SHILLONG URBAN COOPERATIVE BANK.' Working Capital Management is concerned with the issues that occur in the attempt to handle present assets, present liabilities and the interrelationship between them. The goal of Working Capital Management is to manage the current assets and current liabilities of the firm in such a way that the satisfactory level of Working Capital is mentioned. Current assets should be big enough to cover their present liabilities to guarantee a decent security margin.
\end{abstract}

The primary goal of this research is to study the management of working capital and the efficiency of handling a working capital in a business. The secondary objective of this research is to study the optimum level of the company's current assets and current liabilitiesTo study the liquidity situation through different working capital associated ratios, to study economic performance using trend analysis instruments. The study of working capital management is important because, unless the working capital is managed effectively, effectively monitored, properly planned and periodically reviewed at regular intervals to remove bottlenecks, if any, the company can not gain. profits and increase its turnover.

Working Capital research is based on instruments like Trend Analysis, Ratio Analysis, Operating Cycle, etc. Further the research is based on the Annual Reports of the last 5 years. And even factors such as the assessment of rivals, the assessment of the sector was not regarded during the preparation of this project. The secondary technique of information collection is used for this research. The purpose of the information compilation was to study the company's management of working capital. Working capital in the form of current assets is needed to cope with the issue resulting from the absence of instant realization of money against sold products. Therefore, adequate working capital is needed to maintain sales activity.Efficient management of working capital involves firms to work with a certain quantity of net working capital, the precise quantity varying from company to company and depending, among other things; on the nature of the firms. This research has some constraints such as restricted information, restricted period, restricted region, and the length of the research is very small.

Keywords : Capital research,working capital management.

\section{INTRODUCTION}

\section{WORKING CAPITAL}

The uses of a concern's resources can be split into two components, namely long-term funds and short-term funds. Long-term investment can be called ' fixed investment. ' Most long-term funds are invested in fixed assets. These fixed

Revised Manuscript Received on July 22, 2019.

Pavithra Department of Management studies,Bharath Institute of Higher Education and Research,Chennai,India

Kaliyamurthi, Department of Computer Science and Engineering,,Bharath Institute of Higher Education and Research, Chennai, India

P.Thamilselvam, Department of Management studies,Bharath Institute of Higher Education and Research,Chennai,India assets are maintained in the company to gain earnings during the lifetime of the fixed assets. Short-term assets are also needed to operate the company activities. The term working capital is commonly used for the capital required for day-to-day business work, For example, buying raw materials, meeting day-to-day spending on wages, wages, rents, advertising, etc. But there is a lot of dispute among multiple economic officials (financers, accountants, entrepreneurs and economists) about the precise significance of the word working capital.[1-10]

\section{II.DEFINITION}

Working capital relates to the circulating capital needed to satisfy a company firm's day-to-day activities. Working capital can be described by various authors as follows: according to Weston \& Brigham-" Working capital relates to a firm's investment in short-term investments, such as money receivables, inventories, etc.[11-15]

Working capital is current assets. - Mead, Baker and Malott "The sum of present assets is the business ' working capital"J. S. Mill Working capital is described as' the surplus of current assets over current liabilities and regulations.' But as per accounting terminology, there is a distinction between the inflow and outflow of funds.

Working capital is described in the Annual Survey of Industries (1961) as "Stocks of equipment, fuels, semi-finished goods together with work-in-progress and finished goods and products ; money in hand and bank and the algebraic amount of sundry creditors as depicted by (a) stupendous factory payments such as rent, salaries, interest and dividend ; (b) acquire of goods and services ;[15-20]

\section{III.RESEARCH METHODOLOGY}

\section{A.Significance of the study}

We choose the method of working capital management as the research and then build a performance-based collection of leadership scheme. Management objective is the guidelines for the entire management process in a business. In addition to efficiency execution is also required in order to achieve high performance, a matched working capital management strategy should consider the inner and external company environment.[21-24]

\section{IV.OBJECTIVES OF THE STUDY}

B.Primary objective

Studying the management of working capital of The Shillong Co-operative Urban Bank Shillong 


\section{C.Secondary objectives}

The secondary project objectives on Working Capital Management are as follows:To determine policy regarding profitability, performance, liquidity and risk by considering bank' s objectives.

To determine the quantum and structure of current assets.

Determining the relationship between the current assets and current liabilities and, hence, liquidity is determined.

Optimization of the amount of sales and investment in receivables.

Analysis of Financial Statements of the bank.

\section{SCOPE OF THE STUDY}

Working capital management enables us to keep working capital by managing current assets and current liabilities at a satisfactory rate. It also enables considerably keep a correct equilibrium between the business ' profitability, risk and liquidity.[25-27]

Current liabilities are paid on time by handling the working capital. If the company pays its creditors for raw material in a timely manner, it may frequently have the availability of raw material, which does not cause any barriers in the manufacturing process. Adequate working capital improves the company's ability to pay, but the surplus working capital creates more stock, which raises the likelihood of debt delay. On the other side, the lack of sufficient working capital results in a reduction in return on investment. The company's goodwill is also adversely impacted by the failure to pay current liabilities in time. Thus, working capital management enables to handle all the variables that affect working capital in the most lucrative way.[28]

\section{VI.NEED OF THE STUDY}

We choose the method of working capital management as the object of the research and then build a collection of performance-based management scheme. Management objective is the guidelines for the entire leadership cycle in the company. A match-friendly working capital management policy should be considered in terms of the inner and external company setting. While, the final objective relates to the performance-based modifying process of working capital management. What's more, denying and innovating also needs bravery. All in all, the five components of leadership operate together to manage working assets. The research includes all of the present asset elements and present liabilities that play a major part in the profitability of the company.[29]

\section{RESEARCH DESIGN}

The main purpose of this research is to explore the business profitability effect of Working Capital Management. The information reported in this research were gathered from 2012 to 2016 as part of a research to evaluate profitability and management of working capital from financial reports.[30]

\section{D.Data collection methods Primary data}

The information is collected through the primary sources lik
Talking with the employees of the department.

Getting information by observations e.g. in dealing with customer.

Discussion with the Chief Executed Officer.

SECONDARY DThe Data is gathered from secondary sources such as: audited bank accounts. Department's office manuals. - Magazines, bank annual reports. - Documents of policy of different departments.

\section{LIMITATIONS OF THE STUDY}

Window dressing is the topic of the economic statements. It will influence the outcomes of the evaluation method. Absolute numbers can be ornamental as the assessment of the proportion is

\section{IX.ANALYSIS OF DATA AND INTERPRETATION RATIO ANALYSIS}

TABLE NO. 1 CURRENT RATIO

\begin{tabular}{|l|l|l|l|}
\hline Years & $\begin{array}{l}\text { Current Assets } \\
\text { Amt. (Rs.) }\end{array}$ & $\begin{array}{l}\text { Current Liabilities } \\
\text { Amt. (Rs.) }\end{array}$ & $\begin{array}{l}\text { Current Ratio } \\
\text { In Times) }\end{array}$ \\
\hline 2012 & $399,043,073$ & $444,341,147$ & 0.89 \\
\hline 2013 & $617,411,468.20$ & $683,231,253.20$ & 0.90 \\
\hline 2014 & $1,077,461,349$ & $1,012,479,916.87$ & 1.06 \\
\hline 2015 & $1,479,553,994$ & $1,376,357,344.55$ & 1.07 \\
\hline 2016 & $1,340,192,195$ & $1,214,483,241.42$ & 1.10 \\
\hline
\end{tabular}

TABLE NO. 2COMPLETE LIQUID PROPORTION

\begin{tabular}{|l|l|l|l|}
\hline Years & $\begin{array}{l}\text { Cash } \\
\text { Amt. (Rs.) }\end{array}$ & $\begin{array}{l}\text { existing Liabilities } \\
\text { Amt. (Rs.) }\end{array}$ & $\begin{array}{l}\text { complete Liquid } \\
\text { Ratio } \\
\text { In Times) }\end{array}$ \\
\hline 2012 & $21,280,898.60$ & $444,341,147$ & 0.05 \\
\hline 2013 & $680,437,267.70$ & $683,231,253.20$ & 0.11 \\
\hline 2014 & $124,122,507.40$ & $1,012,479,916.87$ & 0.12 \\
\hline 2015 & $14,188,913.33$ & $1,376,357,344.55$ & 0.01 \\
\hline 2016 & 67240377.98 & $1,214,483,241.42$ & 0.05 \\
\hline
\end{tabular}

\section{X.FINDINGS AND SUGGESTIONS}

1. 1. The company's current ratio is greater with 1.10 in 2016 and has risen from year to year.

2. 2. The liquidity situation of the bank continues to rise, slowing down to 0.10 in 2015 and beginning to rise in 2016 .

3. The bank's absolute liquid ratio has been increased to 0.05 in the year 2016 from 0.01 in the year 2015 . 
4. 4. The company's debt equity ratio fell to 0.13 in 2015 and rose the following year. But the bank's debt capability is increasing gradually year after year

5 . The gross profit of the bank is increased to $26.98 \%$ in the year 2016.

6. 6. The bank's net profit declined from 19.46 percent in 2015 to 15.81 percent in 2016. This shows a low safety margin. The bank has to look after the income.The fixed asset turnover ratio is increased from year to year.

7. The current asset ratio went down to 0.07 in the year 2014 from 0.08 in the year 2013. But it gradually started to increase the turnover ratio from 2015-2016.

8. The Working Capital of the company increased to 1.22 times in the year 2014 from 0.76 times in the year 2012 and thereafter the Working Capital of the company has started to decrease.

9. Working Capital modifications are expected to increase in 2012. [31]It therefore refers to the surplus of present liabilities over present assets as the adverse working capital of the company.

\section{RESULTS AND DISCUSSIONS.}

1. 1. It is suggested that the bank take action to preserve the current assets to use the assets to the company for more than a year.

2. 2. It is suggested that the bank take steps to boost income, when sales are fast, little money is bound up to maintain the company going, which can make expansion simpler.

3. 3. Management is recommended to maximize their money flow and should consider paying their bills as quickly as possible. There are, however, risks connected with staying longer than the supplier's terms of trade allow.[32]

4. The company suggests that to concentrate more on net revenue for meeting its better debt capacity.

5. The company suggests that to take necessary steps of the debtors collection period in order to avoid the late payment.

6. The management proposed that measures be taken to increase the working capital to maintain the business for the long term. [33]

\section{XII.CONCLUSION}

Analysis of the management of working capital is an in-depth evaluation. It includes the whole of the company's financial management. The SHILLONG CO-OPERATIVE URBAN BANK is a corporation that offers better customer service to the common people. Any shift in working capital will affect the money flows of a businessA beneficial shift in working capital shows that the company paid money out. An rise in working capital will therefore have a adverse impact on the money holding of the business. A adverse shift in working capital, however, shows a reduced fund to pay off short-term liabilities (present liabilities), which could have a adverse indirect impact on the company's futureTheir now-a-days should be strict eyes watching for the best management of the working capital. Working capital management is a key element of the bank's financial management. SHILLONG CO-OPERATIVE URBAN BANK's assessment of Working Capital Management has disclosed that the current ratio is on the rise. Working Capital Management analyzes have been performed that will assist the business manage its working capital efficiently and effectively. Overall, the business has a good liquidity situation, but as far as current liabilities are concerned, they do not have enough liability repayment resources.

\section{REFERENCES}

1) BharthVajan R., Ramachandran S.,Psychographic dimensions of training,2016,International Journal of Pharmacy and Technology,V-8,I-4,P-23727-23729

2) Balakrishnan P., Bharthvajan R.,A study on human resource planning in hospitals in Chennai City,2014,International Journal of Applied Engineering Research,V-9,I-22,P-7503-7507

3) Priyadarsini P., Bharthvajan R.,Role of emotional intelligence training programme in reducing the stress of the nurses,2014,International Journal of Applied Engineering Research,V-9,I-22,P-7411-7421

4) Kerinab Beenu G., Bharthvajan R.,Empirical analysis on the cosmetic buying behavior of young women in South India,2014,International Journal of Applied Engineering Research,V-9,I-22,P-7361-7366

5) Balakrishnan P., Bharthvajan R.,Whistling in the wind,2014,International Journal of Applied Engineering Research,V-9,I-22,P-7586-7593

6) Krishnan B., Peter M.,Health hazards of Indian Bpo employee-an alarming issue,2014,International Journal of Applied Engineering Research,V-9,I-22,P-7336-7341

7) Kerinab Beenu G.H., Peter M.,Role of insurance in economic development,2014,International Journal of Applied Engineering Research,V-9,I-22,P-7532-7539

8) Balakrishnan P., Peter M., Priyadarsini P.,Efficiency of safety measures for wellbeing of employees in manufacturing industry,2014,International Journal of Applied Engineering Research,V-9,I-22,P-7376-7382

9) Anbarasi M., Praveen Kumar S.,Online sales promotions of herbal products and its effectiveness towards tanisha.com,2019,Indian Journal of Public Health Research and Development,V-10,I-1,P-195-200

10) Anbarasi M., Praveen Kumar S.,Various online marketing and promotions strategies to improve the validation towards the organic products in the pharmaceutical sectors,2019,Indian Journal of Public Health Research and Development,V-10,I-1,P-263-269

11) Loganathan R., Praveen Kumar S.,Grievance handling a key factor for solving issues of employees in an organization,2014,International Journal of Applied Engineering Research,V-9,I-22,P-7483-7491

12) Loganathan R., Praveen Kumar S.,Study on preference of private label brands in super and Hypermarkets,2014,International Journal of Applied Engineering Research,V-9,I-22,P-7327-7335

13) Smitha M., Praveen Kumar S.,Understanding stress and its managementamong the nurses in Chennai city,2014,International Journal of Applied Engineering Research,V-9,I-22,P-7560-7565

14) Kerinab Beenu G.H., Praveen Kumar S.,A study on the investment behavior of Chennai investors in mutual fund schemes,2014,International Journal of Applied Engineering Research,V-9,I-22,P-7520-7525

15) Loganathan R., Praveen Kumar S.,Retention strategies key for organizational productivity,2014,International Journal of Applied Engineering Research,V-9,I-22,P-7443-7447

16) Pavithra J., Ganesan M., Brindha G.,State wise analysis of microfinance sector in India,2016,International Journal of Pharmacy and Technology,V-8,I-4,P-23417-23432

17) Pavithra J., Ganesan M.,A comparative study on microfinance in India and abroad,2016,International Journal of Applied Business and Economic Research,V-14,I-8,P-5471-5476

18) Pavithra J., Ganesan M.,A study on awareness and impact of micro-financial schemes,2016,International Journal of Applied Business and Economic Research,V-14,I-8,P-5449-5460

19) Senthilmurugan P., Pavithra J.,Consumer preference towards organised retailing with reference to Big Bazaar,2014,International Journal of Applied Engineering Research,V-9,I-22,P-7469-7475

20) Senthilmurugan P., Pavithra J.,Implication of social media marketing in growing healthcare industry,2014,International Journal of Applied Engineering Research,V-9,I-22,P-7448-7456

21) Loganathan R., Pavithra J.,Consumer perception towards private label brand over other brands in super markets and hypermarkets,2014,International Journal of Applied Engineering Research,V-9,I-22,P-7355-7360

22) Kerinab Beenu G., Pavithra J.,Tradeâ€"off between liquidity and profitability in logistics 
industry,2014,International Journal of Applied Engineering Research,V-9,I-22,P-7398-7401

23) Kerinab Beenu G., Pavithra J.,A study on the prospective consumerâ€ $€^{\mathrm{TM}_{\mathrm{S}}}$ perception towards utility cars in Chennai city,2014,International Journal of Applied Engineering Research,V-9,I-22,P-7526-7531

24) Pavithra J., Dilli Babu P., Ambuli T.V.,A study on budgetary control at Maruti Service Masters, Chennai,2014,International Journal of Applied Business and Economic Research,V-12,I-2,P-151-161

25) Pavithra J., Dilli Babu P., Ambuli T.V.,A study on customer satisfaction of retro Garments Pvt Ltd, Chennai,2014,International Journal of Applied Business and Economic Research,V-12,I-2,P-381-391

26) Kerinab Beenu G.H., Pavithra J., Senthilmurugan P.,A study on the influence of promotional activities for TATA ARIA among consumers in Chennai,2014,International Journal of Applied Engineering Research,V-9,I-22,P-7572-7578

27) Vijayaragavan S.P.,An investigative expert that's general FBG sensors,International Journal of Mechanical Engineering and Technology,V-8,I-8,PP-1500-1505,Y-2017

28) Vijayaragavan S.P.,Equalization routing protocol for Wi-Fi sensor strategy,International Journal of Mechanical Engineering and Technology,V-8,I-8,PP-1662-1666,Y-2017

29) Karthik B., Kiran Kumar T.V.U., Vijayaragavan P., Bharath Kumaran E.,Design of a digital PLL using 0.35 $\hat{\mathrm{I}}^{1 / 4 \mathrm{~m}}$ CMOS technology,Middle East Journal of Scientific Research,V-18,I-12,PP-1803-1806,Y-2013

30) Kanniga E., Selvaramarathnam K., Sundararajan M.,Kandigital bike operating system,Middle - East Journal of Scientific Research,V

31) Jasmin M., Vigneshwaran T., Beulah Hemalatha S.,Design of power aware on chip embedded memory based FSM encoding in FPGA,International Journal of Applied Engineering Research,V-10,I-2,PP-4487-4496,Y-2015

32) Jasmin M.,Optimization techniques for low power VLSI circuits,Middle - East Journal of Scientific Research,V-20,I-9,PP-1082-1087,Y-2014

33) Jasmin M., Vigneswaran T.,Fuzzy controller for error control of on Chip communication,2017 International Conference on Algorithms, Methodology, Models and Applications in Emerging Technologies, ICAMMAET 2017,V-2017-January,I-,PP-1-5,Y-2017

\section{AUTHORS PROFILE}

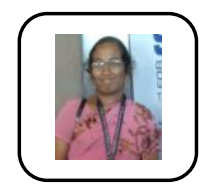

Pavithra, Assistant Professor, Department of Management Studies, Bharath Institute of Higher Education and Research

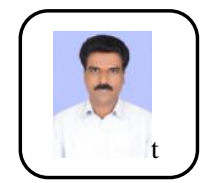

Kaliyamurthi,, Professor, Department of Computer Science and Engineering, Bharath Institute of Higher Education and Research

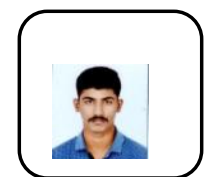

P.Thamilselvam, Student, Department of Management Studies, Bharath Institute of Higher Education and Research 